\title{
Reduction of circulating FABP4 level by treatment with omega-3 fatty acid ethyl esters
}

\author{
Masato Furuhashi", Shinya Hiramitsu², Tomohiro Mita', Akina Omori', Takahiro Fuseya', Shutaro Ishimura', \\ Yuki Watanabe ${ }^{1}$, Kyoko Hoshina ${ }^{1}$, Megumi Matsumoto ${ }^{1}$, Marenao Tanaka', Norihito Moniwa ${ }^{1}$, Hideaki Yoshida', \\ Junnichi Ishii ${ }^{3}$ and Tetsuji Miura ${ }^{1}$
}

\begin{abstract}
Background: Fatty acid-binding protein 4 (FABP4/A-FABP/aP2) mainly expressed in adipocytes is secreted and acts as an adipokine. Increased circulating FABP4 level is associated with obesity, insulin resistance and atherosclerosis. However, little is known about the modulation of serum FABP4 level by drugs including anti-dyslipidemic agents.

Methods: Patients with dyslipidemia were treated with omega-3 fatty acid ethyl esters ( $4 \mathrm{~g} /$ day; $n=14$ ) containing eicosapentaenoic acid (EPA) and docosahexaenoic acid (DHA) for 4 weeks. Serum FABP4 level was measured before and after treatment. Expression and secretion of FABP4 were also examined in mouse 3T3-L1 adipocytes treated with EPA or DHA.

Results: Treatment with omega-3 fatty acid ethyl esters significantly decreased triglycerides and serum FABP4 level $(13.5 \pm 1.5$ vs. $11.5 \pm 1.1 \mathrm{ng} / \mathrm{ml}, P=0.017)$. Change in FABP4 level by omega-3 fatty acids was negatively correlated with change in levels of EPA + DHA $(r=-0.643, P=0.013)$, EPA $(r=-0.540, P=0.046)$ and DHA $(r=-0.650, P=0.011)$ but not change in the level of triglycerides or other fatty acid composition. Treatment of 3T3-L1 adipocytes with EPA or DHA had no effect on short-term (2 h) secretion of FABP4. However, gene expression and long-term (24 h) secretion of FABP4 were significantly reduced by treatment with EPA or DHA.
\end{abstract}

Conclusions: Omega-3 fatty acids decrease circulating FABP4 level, possibly by reducing expression and consecutive secretion of FABP4 in adipocytes. Reducing FABP4 level might be involved in suppression of cardiovascular events by omega-3 fatty acids.

Keywords: Adipokine, Fatty acid-binding protein 4, Adipocyte, Eicosapentaenoic acid, Docosahexaenoic acid

\section{Background}

Fatty acid-binding proteins (FABPs) are predominantly cytosolic proteins that bind hydrophobic ligands, such as long chain fatty acids [1-3]. It has been proposed that FABPs promote the transport of fatty acids to several organelles in the cell [1]. Fatty acid-binding protein 4. (FABP4), also referred to as adipocyte FABP (A-FABP) or aP2, is expressed in adipocytes and macrophages. Previous studies using FABP4-deficient mice

\footnotetext{
* Correspondence: furuhasi@sapmed.ac.jp

${ }^{1}$ Department of Cardiovascular, Renal and Metabolic Medicine, Sapporo Medical University School of Medicine, S-1, W-16, Chuo-ku, Sapporo 060-8543, Japan

Full list of author information is available at the end of the article
}

have demonstrated that FABP4 plays important roles in the development of insulin resistance, diabetes mellitus and atherosclerosis [4-7], and chemical inhibition of FABP4 might be a novel therapeutic agent against insulin resistance, diabetes mellitus and atherosclerosis [8].

It has recently been shown that FABP4 is secreted from adipocytes via a non-classical secretion pathway during lipolysis [9-12], though the sequence of FABP4 lacks signal peptides [1]. Furthermore, FABP4 has been demonstrated to act as an adipokine for the development of insulin resistance in liver [10], suppression of cardiomyocyte contraction [13], inhibition of endothelial nitric oxide synthase in endothelial cells [14] and 
proliferation and migration of vascular smooth muscle cells [15]. It has also been shown that an elevated serum level of FABP4 is associated with obesity, insulin resistance, hypertension, cardiac dysfunction, atherosclerosis and cardiovascular events [9, 16-23]. However, little is known about the alteration of FABP4 level by drugs including anti-dyslipidemic agents.

It has been reported that atorvastatin, a cholesterollowering statin, decreases FABP4 level [24]. Furthermore, omega-3 fatty acids have been reported to inhibit adipocyte differentiation and lipid accumulation in vitro, possibly leading to a decrease in the expression of FABP4, also known as a differentiation marker of adipocytes [25-27]. We hypothesized that modulation of lipid levels by drugs can decrease the circulating FABP4 level. In this study, we investigated the effect of omega-3 fatty acid ethyl esters containing eicosapentaenoic acid (EPA) and docosahexaenoic acid (DHA) on serum FABP4 level in patients with dyslipidemia. We also examined druginduced regulation of the expression and secretion of FABP4 in adipocytes in the presence or absence of lipolytic stimulation.

\section{Methods}

Human study (Study 1) conformed to the principles outlined in the Declaration of Helsinki and was performed with the approval of the Ethical Committee of Fujita Health University. Written informed consent was received from all of the subjects. Experimental procedures for in vitro study using mouse 3T3-L1 adipocytes (Study 2) were performed with approval from the Animal Care and Experiment Committee of Sapporo Medical University.

\section{Study 1: Effects of omega-3 fatty acids on serum FABP4 level}

Male patients with dyslipidemia $(n=14$; mean age: $40.2 \pm 1.7$ years) were enrolled from outpatient clinics affiliated with Fujita Health University. Entry criteria were no treatment with lipid-lowering agents, antidiabetic agents or antihypertensive agents and absence of complications such as hepatic disease, cerebrovascular or cardiovascular disease, or renal disease. Patients were treated with $4 \mathrm{~g}$ ( $2 \mathrm{~g}$ twice daily; after breakfast and dinner) omega-3 fatty acid ethyl esters containing 1,860 mg/day EPA ethyl ester and 1,500 $\mathrm{mg} /$ day DHA ethyl ester for 4 weeks in outpatient clinics.

\section{Measurements}

Body mass index (BMI, $\mathrm{kg} / \mathrm{m}^{2}$ ) was calculated as body weight divided by the square of body height. Before and after the 4-week treatment with omega-3 fatty acid ethyl esters, blood samples were collected after an overnight fast, and serum and plasma samples were analyzed immediately or stored at $-80{ }^{\circ} \mathrm{C}$ until biochemical analyses. Serum FABP4 concentration was measured using an enzyme-linked immunosorbent assay kit (Biovendor R\&D, Modrice, Czech Republic). Precision, accuracy and reproducibility of the kit have been described previously [9]. Hemoglobin A1c (HbA1c) was determined by a latex coagulation method and was expressed in NGSP scale. Plasma glucose and fasting plasma insulin was measured by the glucose oxidase method and a radioimmunoassay method, respectively. Levels of creatinine $(\mathrm{Cr})$, triglycerides, total cholesterol and high-density lipoprotein (HDL) cholesterol were determined by enzymatic methods. Level of low-density lipoprotein (LDL) cholesterol was calculated by the Friedewald equation. The compositions of 24 fatty acids, including lauric acid (C12:0), myristic acid (C14:0), myristoleic acid (C14:1 $\omega 5)$, palmitic acid (C16:0), palmitoleic acid

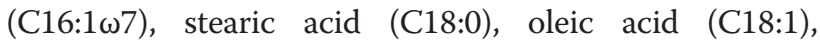

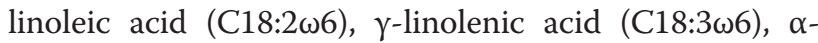
linolenic acid (C18:3 $\omega 3)$, arachidic acid (C20:0),

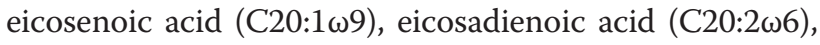
eicosatetraenoic acid (C20:3 $\omega 9)$, dihomo- $\gamma$-linolenic acid

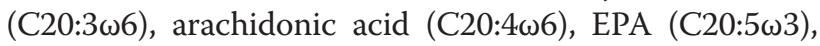
behenic acid (C22:0), erucic acid (C22:1 $\omega 9)$, docosate-

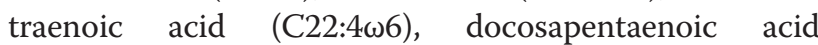

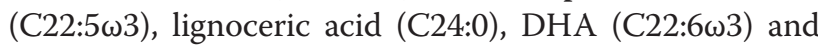
nervonic acid (C24:1 $\omega 9)$, were determined by using capillary gas chromatography. High-sensitivity C-reactive protein (hsCRP) was measured by a nephelometry method. Serum level of high-molecular weight (HMW)adiponectin was measured using a commercially available chemiluminescent enzyme immunoassay kit (Fujirebio, Tokyo, Japan). Estimated glomerular filtration rate (eGFR), an index of renal function, was calculated by an equation for Japanese [28]: eGFR $\left(\mathrm{ml} / \mathrm{min} / 1.73 \mathrm{~m}^{2}\right)=$ $194 \times \mathrm{Cr}^{(-1.094)} \times$ age $^{(-0.287)} \times 0.739$ (if female). HOMAIR, an index of insulin resistance, was calculated by the previously reported formula: insulin $(\mu \mathrm{U} / \mathrm{ml}) \times$ glucose (mg/dl) / 405.

\section{Study 2: Effects of omega-3 fatty acids on expression and secretion of FABP4 in mouse 3T3-L1 adipocytes}

All biochemical reagents were obtained from SigmaAldrich (St. Louis, MO) unless otherwise indicated. Preadipocyte 3T3-L1 cells were purchased from Health Science Research Resources Bank (Osaka, Japan). Differentiation of 3T3-L1 cells into adipocytes was induced as previously described [11]. Differentiated 3T3$\mathrm{L} 1$ adipocytes were stimulated for $2 \mathrm{~h}$ (short-term secretion analysis) in the presence and absence of $10 \mu \mathrm{M}$ isoproterenol or $24 \mathrm{~h}$ (long-term secretion and gene expression analyses) with $0-100 \mu \mathrm{M}$ EPA or $0-100 \mu \mathrm{M}$ DHA in Dulbecco's Modified Eagle's Medium (DMEM) 
(Invitrogen, Carlsbad, CA) supplemented with $0.5 \%$ fatty acid-depleted BSA. The doses of reagents and incubation periods were varied according to the experimental protocol. Each experiment was performed in at least triplicate.

\section{Quantitative real-time PCR}

Total RNA was isolated using Trizol Reagent (Invitrogen), and cDNA was synthesized using a kit (Applied Biosystems, Foster City, CA). Quantitative real-time PCR analysis using SYBR Green was performed (Applied Biosystems). The thermal cycling program was $10 \mathrm{~min}$ at $95^{\circ} \mathrm{C}$ for enzyme activation and 40 cycles of denaturation for $15 \mathrm{~s}$ at $95{ }^{\circ} \mathrm{C}, 30$-s annealing at $58{ }^{\circ} \mathrm{C}$ and 35 -s extension at $72{ }^{\circ} \mathrm{C}$. Two pairs of specific primers used are as follows: 5' - AAG GTG AAG AGC ATC ATA ACC CT $-3^{\prime}$ and 5'- TCA CGC CTT TCA TAA CAC ATT CC $-3^{\prime}$ for FABP4, 5' - TCG CTG ATG CAC TGC CTA TG $-3^{\prime}$ and 5'- GAG AGG TCC ACA GAG CTG ATT $3^{\prime}$ for peroxisome proliferator-activated receptor (PPAR)- $\gamma 2$, 5'- CAA GAA CAG CAA CGA GTA CCG -3' and 5' - GTC ACT GGT CAA CTC CAG CAC - $3^{\prime}$ for CCAAT/enhancer binding protein $\alpha(\mathrm{C} / \mathrm{EBP} \alpha)$ and $5^{\prime}-\mathrm{AGT}$ CCC TGC CCT TTG TAC ACA -3' and 5'- CGA TCC GAG GGC CTC ACT A -3' for 18s rRNA as an internal control gene.

\section{Western blot analysis}

The conditioned medium (CM) isolated from adipocytes was filtered to obtain $10-50-\mathrm{kDa}$ fractions of proteins using Amicon Ultra $10 \mathrm{~K}$ and $50 \mathrm{~K}$ devices (Millipore, Billerica, MA). For lysing cells, a cell lysis buffer, containing $50 \mathrm{mM}$ Tris- $\mathrm{HCl}$ (pH 7.0), $5 \mathrm{mM}$ EDTA, 2 mM EGTA, $10 \mathrm{mM} \quad \mathrm{Na}_{4} \mathrm{P}_{2} \mathrm{O}_{7}, 10 \mathrm{mM} \quad \mathrm{Na}_{3} \mathrm{VO}_{4}, 40 \mathrm{mM} \quad \beta-$ glycerophosphate, $30 \mathrm{mM} \mathrm{NaF}, 0.5 \% \mathrm{NP}-40$, and $1 \%$ protease inhibitor cocktail, was used. Total protein content of the cell lysate $(\mathrm{CL})$ was assessed by a microplate protein assay based on the Lowry method (Bio-Rad, Hercules, CA).

Equal protein amounts per the $\mathrm{CL}$ and the filtered $\mathrm{CM}$ were subjected to SDS-polyacrylamide gel electrophoresis and electrophoretically transferred onto PVDF membranes (Whatman, Florham Park, NJ). After incubation for $1 \mathrm{~h}$ at room temperature with a blocking solution of $3 \%$ BSA in Tris-buffered saline buffer containing $0.1 \%$ Tween 20 (TBST), the membranes were incubated with primary antibodies for FABP4 (\#ab13979; Abcam, Tokyo, Japan) and glyceraldehyde 3-phosphate dehydrogenase (GAPDH) (\#sc-20357; Santa Cruz Biotechnology, Santa Cruz, CA) overnight at $4{ }^{\circ} \mathrm{C}$. After washing with TBST, the membranes were incubated with a secondary antibody conjugated with horseradish peroxidase (Santa Cruz Biotechnology) for $1 \mathrm{~h}$ at room temperature and washed. Immunodetection was performed using a chemiluminescence kit (Roche Diagnostics, Tokyo, Japan). Densitometry analysis was performed using ImageJ software. FABP4 secretion was expressed as densitometry of FABP4 in the CM divided by those of FABP4 in the CL and GAPDH in the CL as previously described [29].

\section{Statistical analysis}

Numeric variables are expressed as means \pm SEM. For regression analyses, the distribution normality of each parameter was checked using the Shapiro-Wilk W test, and non-normally distributed parameters were logarithmically transformed. The correlation between two parameters was evaluated using Pearson's correlation coefficient. Comparison between paired samples was done with Wilcoxon signed-rank test. For detecting significant differences in data between more than two groups, one-way analysis of variance and Tukey-Kramer post hoc test were used. A p value of less than 0.05 was considered statistically significant. All data were analyzed by using JMP 9 for Macintosh (SAS Institute, Cary, NC).

\section{Results}

Study 1

Characteristics of the patients are shown in Table 1. No one dropped out from the protocol in Study 1 . Treatment with omega-3 fatty acid ethyl esters for 4 weeks significantly decreased triglycerides $(163.7 \pm 20.6$ vs. $98.1 \pm 11.4 \mathrm{mg} / \mathrm{dl}, \quad P=0.003)$, but no significant

Table 1 Characteristics of the male patients (Omega-3 FAs, 4w)

\begin{tabular}{lll}
\hline & Pre & Post \\
\hline $\mathrm{n}$ & 14 & \\
Age (years) & $40.2 \pm 1.7$ & \\
Body mass index $(\mathrm{kg} / \mathrm{m} 2)$ & $25.9 \pm 0.7$ & $26.1 \pm 0.7$ \\
Waist circumference $(\mathrm{cm})$ & $89.5 \pm 1.8$ & $89.0 \pm 2.0$ \\
Biochemical data & & \\
Total cholesterol $(\mathrm{mg} / \mathrm{dl})$ & $217.2 \pm 7.1$ & $207.6 \pm 8.5$ \\
HDL cholesterol $(\mathrm{mg} / \mathrm{dl})$ & $57.6 \pm 3.7$ & $57.6 \pm 4.3$ \\
LDL cholesterol $(\mathrm{mg} / \mathrm{dl})$ & $132.6 \pm 6.5$ & $125.8 \pm 8.3$ \\
Triglycerides $(\mathrm{mg} / \mathrm{dl})$ & $163.7 \pm 20.6$ & $98.1 \pm 11.4^{*}$ \\
Glucose $(\mathrm{mg} / \mathrm{dl})$ & $97.6 \pm 2.2$ & $98.0 \pm 1.8$ \\
Insulin $(\mu \mathrm{U} / \mathrm{ml})$ & $7.9 \pm 1.9$ & $6.5 \pm 1.2$ \\
HOMA-IR & $1.99 \pm 0.56$ & $1.57 \pm 0.28$ \\
HbA1c $(\%)$ & $5.5 \pm 0.1$ & $5.5 \pm 0.1$ \\
hsCRP (mg/dl) & $0.60 \pm 0.17$ & $0.75 \pm 0.20$ \\
HMW-adiponectin $(\mu \mathrm{g} / \mathrm{ml})$ & $2.42 \pm 0.23$ & $2.31 \pm 0.23$ \\
FABP4 (ng/ml) & $13.5 \pm 1.5$ & $11.5 \pm 1.1^{*}$ \\
\hline
\end{tabular}

Variables are expressed as $\mathrm{n}$ or means \pm SEM

hsCRP high-sensitivity C-ractive protein, HMW high-molecular weight ${ }^{*} P<0.05$ vs. Pre 
differences were found before and after treatment in waist circumference, BMI or levels of glucose, insulin, HOMA-IR, total cholesterol, LDL cholesterol, HDL cholesterol, hsCRP or HMW-adiponectin. Regarding fatty acid composition, treatment with omega-3 fatty acid ethyl esters significantly increased EPA (48.6 \pm 5.3 vs. $144.6 \pm 12.4 \mu \mathrm{g} / \mathrm{ml}, P<0.001)$, DHA $(139.8 \pm 8.2$ vs.
$179.5 \pm 7.6 \mu \mathrm{g} / \mathrm{ml}, P<0.001)$, behenic acid and docosapentaenoic acid and conversely decreased palmitic acid, palmitoleic acid, oleic acid, linoleic acid, $\gamma$-linolenic acid, eicosadienoic acid, eicosatetraenoic acid, dihomo- $\gamma$ linolenic acid, arachidonic acid, docosatetraenoic acid and total fatty acids (Table 2). Serum FABP4 level was significantly decreased by $14.8 \%$ after treatment with

Table 2 Fatty acid composition (Omega-3 FAs, 4w)

\begin{tabular}{|c|c|c|c|c|c|}
\hline & & $\mu \mathrm{g} / \mathrm{ml}$ & & $\%$ vol & \\
\hline & & Pre & Post & Pre & Post \\
\hline Saturated fatty acids & & & & & \\
\hline Lauric acid & C12:0 & $5.4 \pm 0.9$ & $3.4 \pm 0.6$ & $0.16 \pm 0.02$ & $0.12 \pm 0.02$ \\
\hline Myristic acid & C14:0 & $31.0 \pm 4.2$ & $20.7 \pm 2.2$ & $0.89 \pm 0.09$ & $0.71 \pm 0.06$ \\
\hline Palmitic acid & C16:0 & $607.5 \pm 40.8$ & $491.0 \pm 18.3^{*}$ & $17.7 \pm 0.4$ & $17.0 \pm 0.3$ \\
\hline Stearic acid & C18:0 & $304.6 \pm 20.0$ & $265.2 \pm 11.0$ & $8.9 \pm 0.3$ & $9.2 \pm 0.2$ \\
\hline Arachidic acid & C20:0 & $2.0 \pm 0.2$ & $1.6 \pm 0.1$ & $0.058 \pm 0.004$ & $0.055 \pm 0.004$ \\
\hline Behenic acid & $\mathrm{C} 22: 0$ & $1.1 \pm 0.1$ & $1.9 \pm 0.2^{*}$ & $0.0077 \pm 0.0077$ & $0.092 \pm 0.014^{*}$ \\
\hline Lignoceric acid & C24:0 & $0.81 \pm 0.06$ & $0.75 \pm 0.03$ & $0.025 \pm 0.001$ & $0.027 \pm 0.002$ \\
\hline Monounsaturated fatty acids & & & & & \\
\hline Myristoleic acid & C14:1w5 & $3.0 \pm 0.6$ & $1.4 \pm 0.2^{*}$ & $0.083 \pm 0.016$ & $0.048 \pm 0.006$ \\
\hline Palmitoleic acid & $\mathrm{C} 16: 1 \omega 7$ & $66.2 \pm 6.8$ & $42.2 \pm 3.9^{*}$ & $1.9 \pm 0.1$ & $1.4 \pm 0.1^{*}$ \\
\hline Oleic acid & 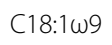 & $749.7 \pm 66.9$ & $526.7 \pm 36.5^{*}$ & $21.6 \pm 0.9$ & $18.0 \pm 0.6^{*}$ \\
\hline Eicosenoic acid & 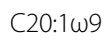 & $6.0 \pm 0.7$ & $5.3 \pm 0.6$ & $0.17 \pm 0.01$ & $0.18 \pm 0.02$ \\
\hline Erucic acid & 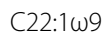 & $3.4 \pm 0.2$ & $3.3 \pm 0.1$ & $0.10 \pm 0.01$ & $0.11 \pm 0.01$ \\
\hline Nervonic acid & $C 24: 1 \omega 9$ & $1.9 \pm 0.1$ & $1.9 \pm 0.1$ & $0.060 \pm 0.048$ & $0.068 \pm 0.005$ \\
\hline Polyunsaturated fatty acids & & & & & \\
\hline Omega-3 fatty acids & & & & & \\
\hline a-Linolenic acid & C18:3w3 & $26.9 \pm 2.7$ & $22.3 \pm 2.8$ & $0.78 \pm 0.05$ & $0.75 \pm 0.07$ \\
\hline Eicosapentaenoic acid (EPA) & C20:5w3 & $48.6 \pm 5.3$ & $144.6 \pm 12.4^{*}$ & $1.5 \pm 0.2$ & $5.0 \pm 0.6^{*}$ \\
\hline Docosapentaenoic acid & $C 22: 5 \omega 3$ & $19.8 \pm 1.2$ & $25.7 \pm 1.4^{*}$ & $0.59 \pm 0.04$ & $0.90 \pm 0.05^{*}$ \\
\hline Docosahexaenoic acid (DHA) & C22:6w3 & $139.8 \pm 8.2$ & $179.5 \pm 7.6^{*}$ & $4.2 \pm 0.3$ & $6.4 \pm 0.4^{*}$ \\
\hline Omega- 6 fatty acids & & & & & \\
\hline Linoleic acid & C18:2w6 & $1064.3 \pm 46.2$ & $894.0 \pm 54.3^{*}$ & $31.6 \pm 0.9$ & $30.6 \pm 1.1$ \\
\hline$y$-linolenic acid & C18:3w6 & $11.0 \pm 1.5$ & $6.4 \pm 1.0^{*}$ & $0.32 \pm 0.04$ & $0.22 \pm 0.03^{*}$ \\
\hline Eicosadienoic acid & $C 20: 2 \omega 6$ & $6.9 \pm 0.5$ & $4.7 \pm 0.3^{*}$ & $0.20 \pm 0.01$ & $0.16 \pm 0.01^{*}$ \\
\hline Dihomo- $\gamma$-linolenic acid & $C 20: 3 \omega 6$ & $47.2 \pm 3.4$ & $27.4 \pm 3.1^{*}$ & $1.4 \pm 0.1$ & $1.0 \pm 0.1^{*}$ \\
\hline Arachidonic acid (AA) & 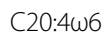 & $248.0 \pm 14.8$ & $222.4 \pm 12.1^{*}$ & $7.5 \pm 0.4$ & $7.8 \pm 0.3$ \\
\hline Docosatetraenoic acid & $\mathrm{C} 22: 4 \omega 6$ & $4.7 \pm 0.3$ & $2.8 \pm 0.2^{*}$ & $0.14 \pm 0.01$ & $0.10 \pm 0.01^{*}$ \\
\hline Omega-9 fatty acids & & & & & \\
\hline Eicosatetraenoic acid & $c 20: 3 \omega 9$ & $1.5 \pm 0.1$ & $1.1 \pm 0.1^{*}$ & $0.045 \pm 0.002$ & $0.035 \pm 0.002^{*}$ \\
\hline Total fatty acids & & $3402.8 \pm 181.2$ & $2899.1 \pm 120.0^{*}$ & 100 & 100 \\
\hline Calculation & & & & & \\
\hline EPA/AA & & $0.20 \pm 0.02$ & $0.68 \pm 0.07^{*}$ & & \\
\hline DHA/AA & & $0.57 \pm 0.03$ & $0.83 \pm 0.04^{*}$ & & \\
\hline$E P A+D H A$ & & $188.4 \pm 12.2$ & $324.2 \pm 18.6^{*}$ & $5.7 \pm 0.5$ & $11.4 \pm 1.0^{*}$ \\
\hline$(E P A+D H A) / A A$ & & $0.78 \pm 0.05$ & $1.50 \pm 0.11^{*}$ & & \\
\hline
\end{tabular}


omega-3 fatty acid ethyl esters ( $13.5 \pm 1.5$ vs. $11.5 \pm 1.1$ $\mathrm{ng} / \mathrm{ml}, P=0.017$ ) (Fig. 1a). Change (Post - Pre) in FABP4 level was negatively correlated with change in levels of EPA + DHA ( $\mathrm{r}=-0.643, P=0.013)$ (Fig. 1b), EPA $(\mathrm{r}=$ $-0.540, P=0.046)$ (Fig. 1c) and DHA $(\mathrm{r}=-0.650, P=$ 0.011) (Fig. 1d). However, change in FABP4 level was not correlated with change in levels of total fatty acids $(\mathrm{r}=-0.003, P=0.911)$ (Fig. 1e), triglycerides $(\mathrm{r}=-0.019, P=0.948)$ (Fig. 1f) or other fatty acid composition.

\section{Study 2}

Treatment with both EPA and DHA for $24 \mathrm{~h}$ significantly decreased gene expression of FABP4 in 3T3-L1 adipocytes in a dose-dependent manner, and the effect tended to be more augmented with DHA treatment than with EPA treatment (Fig. 2a, b). Furthermore, both EPA and DHA significantly decreased gene expression of PPAR 2 and C/EBP $\alpha$ in 3T3-L1 adipocytes in a dosedependent manner (Fig. 2c-f). Western blot analysis showed that FABP4, but not a non-secretory protein GAPDH, was present in the CM of 3T3-L1 (Fig. 2g, h), indicating that FABP4 is secreted from adipocytes without cell destruction. FABP4 secretion was induced by lipolytic stimulation with $10 \mu \mathrm{M}$ isoproterenol, a pan- $\beta$ adrenergic agonist, for $2 \mathrm{~h}$ (Fig. $2 \mathrm{~g}$ ) as previously reported [11]. Treatment with $50 \mu \mathrm{M}$ EPA or $50 \mu \mathrm{M}$ DHA for $2 \mathrm{~h}$ (short-term) did not significantly change FABP4 secretion from adipocytes in the absence or presence of $10 \mu \mathrm{M}$ isoproterenol (Fig. 2g). However, a
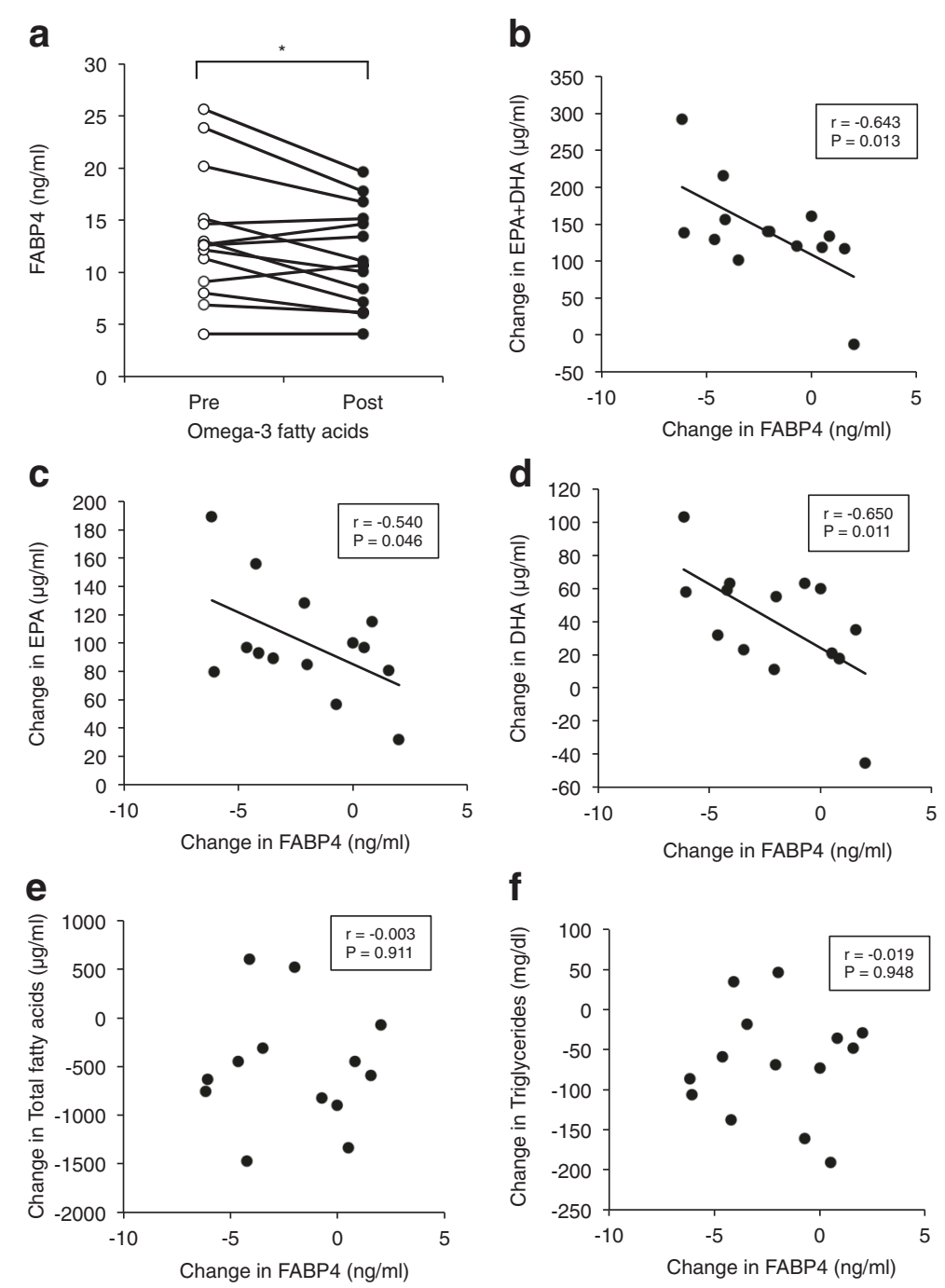

Fig. 1 Effect of omega-3 fatty acid ethyl esters on FABP4 level (Study 1). a. Treatment with $4 \mathrm{~g}$ (2 g twice daily) omega-3 fatty acid ethyl esters, containing 1,860 mg/day eicosapentaenoic acid (EPA) ethyl ester and 1,500 mg/day docosahexaenoic acid (DHA) ethyl ester, for 4 weeks significantly decreased FABP4 levels in male patients with hypertriglycemia $(n=14) .{ }^{*} P<0.05$. b-d. Changes (Post - Pre) in levels of EPA + DHA (b), EPA (c), DHA (d), total fatty acids (e) and triglycerides (f) were plotted against change in level of FABP4 for each subject 
a

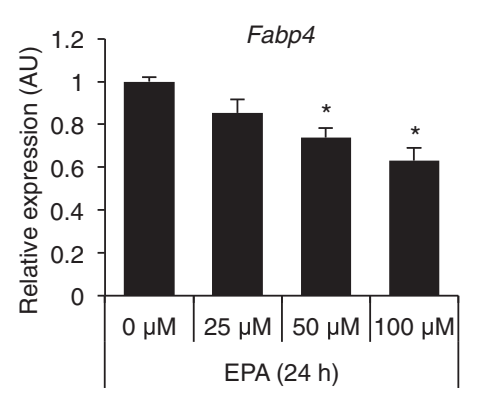

C

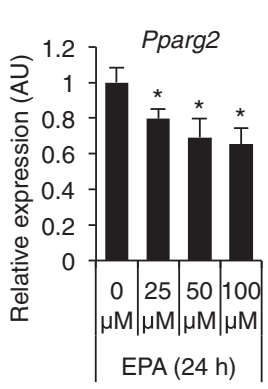

d

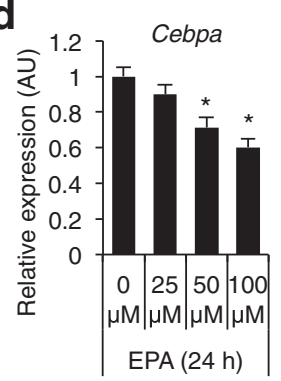

b

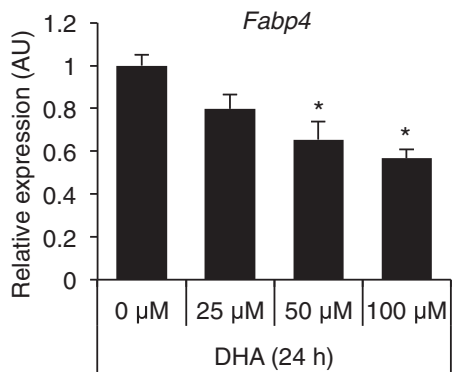

e

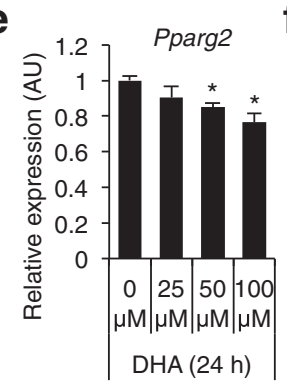

f

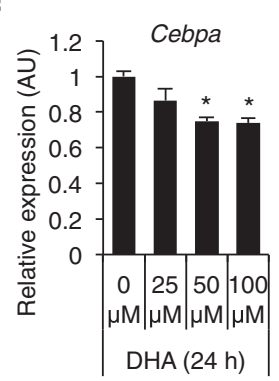

g

For $2 \mathrm{~h}$
Isoproterenol

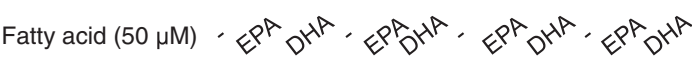

FABP4 GAPDH
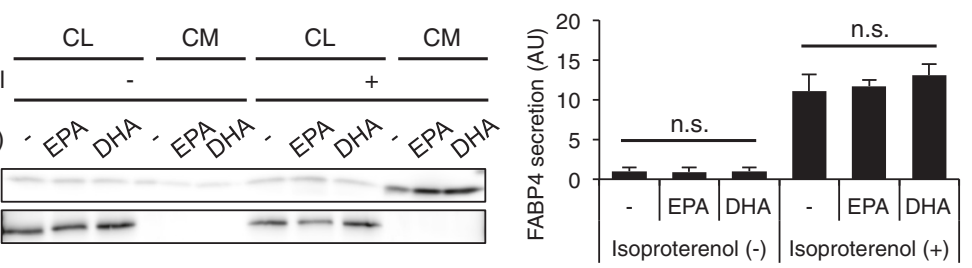

h
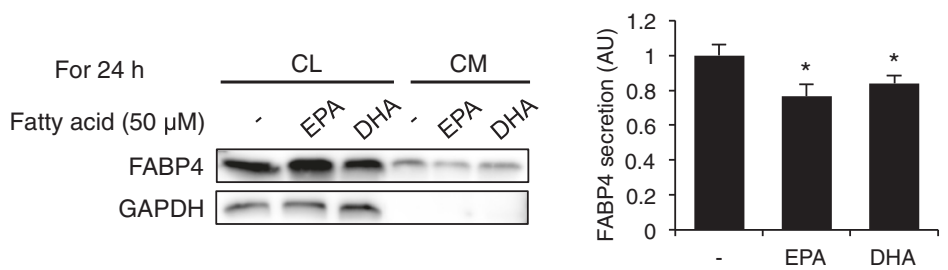

Fig. 2 Gene expression and secretion of FABP4 in 3T3-L1 adipocytes treated with omega-3 fatty acids (Study 2). $\mathbf{a}$, b. Gene expression of FABP4 was determined by quantitative real-time PCR in differentiated 3T3-L1 adipocytes treated with 0-100 $\mu \mathrm{M}$ eicosapentaenoic acid (EPA) (A) or $0-100 \mu \mathrm{M}$ docosahexaenoic acid (DHA) (B) for $24 \mathrm{~h}$ ( $n=3$ in each group). ${ }^{*} P<0.05 \mathrm{vs}$. $0 \mu \mathrm{M}$. c-f. Gene expression of peroxisome proliferator-activated receptor Y2 (PPARY2) and CCAAT/enhancer binding protein a (C/EBPa) was determined by quantitative real-time PCR in differentiated 3T3-L1 adipocytes

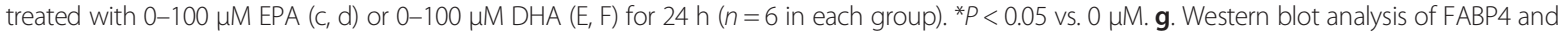
glyceraldehyde 3-phosphate dehydrogenase (GAPDH) using the cell lysate (CL) and conditioned medium (CM) of 3T3-L1 adipocytes treated with $50 \mu \mathrm{M}$ EPA or $50 \mu \mathrm{M}$ DHA in the absence and presence of $10 \mu \mathrm{M}$ isoproterenol for $2 \mathrm{~h}(n=5 \mathrm{in}$ each group). n.s., not significant. $\mathbf{h}$. Western blot analysis of FABP4 and GAPDH using the CL and CM of 3T3-L1 adipocytes treated with $50 \mu \mathrm{M}$ EPA or $50 \mu \mathrm{M}$ DHA for $24 \mathrm{~h}$ ( $n=5$ in each group). FABP4 secretion was relatively expressed as densitometry of FABP4 in the $C M$ divided by those of FABP4 in the $C L$ and GAPDH in the $C L$. $A U$, arbitrary unit. ${ }^{*} P<0.05$ vs. Fatty acid (-)

significant decrease of FABP4 secretion from adipocytes was observed at $24 \mathrm{~h}$ (long-term) after treatment with $50 \mu \mathrm{M}$ EPA or $50 \mu \mathrm{M}$ DHA (Fig. 2h).

\section{Discussion}

The present study demonstrated for the first time that treatment with omega-3 fatty acid ethyl esters containing EPA and DHA for 4 weeks significantly decreased serum FABP4 concentration in patients with dyslipidemia.
Furthermore, in vitro experiments showed that treatment with EPA or DHA dose-dependently (up to 100 $\mu \mathrm{M})$ decreased the expression and consecutive longterm secretion, but not short-term secretion, of FABP4 in 3T3-L1 adipocytes. Average changes in the levels of EPA and DHA by treatment with omega-3 fatty acid ethyl esters were $96.0 \mu \mathrm{g} / \mathrm{ml}(317 \mu \mathrm{M})$ and $39.7 \mu \mathrm{g} / \mathrm{ml}$ $(121 \mu \mathrm{M})$, respectively, in the present study, indicating that the doses of EPA and DHA in in vitro experiments 
were physiological but not pharmacological. These findings suggest that a direct suppressive effect of omega-3 fatty acids on FABP4 expression and its consecutive secretion in adipocytes plays a role in the decrease in serum FABP4 level.

In the present study, treatment with omega-3 fatty acid ethyl esters significantly decreased triglycerides and total fatty acids and modulated levels of fatty acid composition. However, changes in the levels of triglycerides, total fatty acids and each fatty acid composition except for EPA and DHA were not correlated with reduction of FABP4 level, suggesting that qualitative, but not quantitative, change in fatty acids contributes to the reduction in FABP4 concentration. It has been reported that expression of FABP4 in adipocytes is up-regulated by PPAR $\gamma$ agonists and saturated and monounsaturated fatty acids [1, 2, 30-32]. On the other hand, polyunsaturated fatty acids, such as omega- 3 fatty acids, have been reported to inhibit adipocyte differentiation and lipid accumulation, leading to a decrease in the expression of FABP4, also known as an adipocyte differentiation marker [25-27]. Furthermore, it has been shown that unsaturated fatty acids, including EPA, repress expression of FABP4 in RAW264.7 macrophages [33], though the predominant contributors of circulating FABP4 are adipocytes rather than macrophages [10]. In the present study, we showed that both EPA and DHA decreased FABP4 expression even in differentiated 3T3-L1 adipocytes, at least in part, via reduction in gene expression of PPAR 2 and C/EBP $\alpha$, which are critical transcription factors for regulation of adipocyte differentiation [34].

There have been some reports about modulation of FABP4 concentration by drugs. Atorvastatin, a cholesterol-lowering statin, has been reported to decrease FABP4 level, but the mechanism is totally unknown [24]. It has also been shown that several angiotensin II receptor blockers (ARBs) decrease circulating FABP4 concentration [29, 35], and reduction of sympathetic nerve activation due to a class effect of ARBs, but not a direct effect of angiotensin II receptor blockade, has been postulated as a possible mechanism of decreased FABP4 level by ARBs [29], since FABP4 secretion from adipocytes is associated with $\beta$-adrenergic receptor-mediated lipolysis $[10,11]$. Previous studies showed that dietary fish and omega-3 fatty acid consumption decreased sympathetic nerve activity [36, 37]. Other than direct suppressive effects of EPA and DHA on FABP4 expression in adipocytes, treatment with omega-3 fatty acid ethyl esters containing EPA and DHA may decrease FABP4 concentration by inhibiting FABP4 secretion from adipocytes associated with sympathetic tone-mediated lipolysis.

Previous studies including a recent meta-analysis have shown that both dietary and circulating EPA and DHA are associated with the low incidence of cardiovascular disease in a multiethnic population [38, 39]. Furthermore, recent clinical trials have demonstrated that omega-3 fatty acids, including EPA alone, EPA + DHA and fish oil, substantially reduce cardiovascular events [40-43]. Since there is accumulating evidence demonstrating significant roles of circulating FABP4 in insulin resistance, atherosclerosis and cardiovascular events [10, $14,15,17,21-23]$, the results of the present study support the notion that reduction of FABP4 concentration is one of the important mechanisms by which omega-3 fatty acids prevent the development of cardiovascular disease.

The present study has several limitations. The number of patients recruited in Study 1 was small, and the possibility of a type 1 error cannot be excluded. Since it has been reported that there is a gender difference in serum FABP4 levels $[9,18]$, we recruited only male patients to reduce confounding factors. The present study also lacked a placebo control group. Interventional studies of placebo-control design using larger numbers of both male and female patients are necessary for evaluating the impact of omega-3 fatty acids on circulating FABP4 level. Furthermore, mouse 3T3-L1 adipocytes, a well-used cell line of adipocytes, were used in vitro experiments, but there might be a difference between mice and humans in regulation of the expression and secretion of FABP4 by omega-3 fatty acids. Lastly, there has been accumulating evidence indicating FABP4 is expressed in several types of cells, in addition to adipocytes and macrophages, under both physiological and pathological conditions [2, 3, 44-48]. Omega-3 fatty acids may affect the expression and secretion of FABP4 in cells other than adipocytes, though the predominant contributors of circulating FABP4 level are adipocytes rather than macrophages and other cells $[3,10]$.

\section{Conclusions}

Treatment with omega-3 fatty acid ethyl esters containing EPA and DHA decreases serum FABP4 concentration in patients with dyslipidemia, at least in part, via a direct reduction in expression and consecutive secretion of FABP4 in adipocytes. Suppression of FABP4 levels may lead to the reduction of cardiovascular events as a pleiotropic effect of supplements of omega-3 fatty acids.

\section{Competing interests}

The authors declare that they have no competing interests.

\section{Authors' contributions}

Design of the study: MF, SH, J. Management of acquisition of data: $\mathrm{SH}, \mathrm{Jl}$. Analysis of data: MF. TMita, AO, TF, SI, YW, KH, MM, MT, NM, HY. Draft of the manuscript: MF, TMiura. All authors read and approved the final manuscript. 


\section{Acknowledgements}

We thank Ms. Shiho Ishikawa for technical help. M.F. has been supported by grants from JSPS KAKENHI, MEXT Translational Research Network Program, Uehara Memorial Foundation, SENSHIN Medical Research Foundation, Japan Diabetes Foundation, Takeda Medical Research Foundation, Ono Medical Research Foundation, Takeda Science Foundation, Akiyama Life Science Foundation, Yamaguchi Endocrine Research Foundation, Naito Foundation Natural Science Scholarship, Suhara Memorial Foundation and Kondou Kinen Medical Foundation.

\section{Author details}

${ }^{1}$ Department of Cardiovascular, Renal and Metabolic Medicine, Sapporo Medical University School of Medicine, S-1, W-16, Chuo-ku, Sapporo 060-8543, Japan. ${ }^{2}$ Hiramitsu Heart Clinic, Shiroshita-cho 2-35, Minami-ku, Nagoya 457-0047, Aichi, Japan. ${ }^{3}$ Department of Joint Research Laboratory of Clinical Medicine, Fujita Health University School of Medicine, Toyoake 470-1192, Aichi, Japan

\section{Received: 16 December 2015 Accepted: 4 January 2016}

\section{Published online: 12 January 2016}

\section{References}

1. Furuhashi M, Hotamisligil GS. Fatty acid-binding proteins: role in metabolic diseases and potential as drug targets. Nat Rev Drug Discov. 2008;7:489-503.

2. Furuhashi M, Ishimura S, Ota H, Miura T. Lipid chaperones and metabolic inflammation. Int J Inflam. 2011;2011:642612.

3. Furuhashi M, Saitoh S, Shimamoto K, Miura T. Fatty Acid-Binding Protein 4 (FABP4): Pathophysiological Insights and Potent Clinical Biomarker of Metabolic and Cardiovascular Diseases. Clin Med Insights Cardiol. 2014;8:23-33.

4. Hotamisligil GS, Johnson RS, Distel RJ, Ellis R, Papaioannou VE, Spiegelman BM. Uncoupling of obesity from insulin resistance through a targeted mutation in aP2, the adipocyte fatty acid binding protein. Science. 1996;274: 1377-9.

5. Makowski L, Boord JB, Maeda K, Babaev VR, Uysal KT, Morgan MA, et al. Lack of macrophage fatty-acid-binding protein aP2 protects mice deficient in apolipoprotein E against atherosclerosis. Nat Med. 2001;7:699-705.

6. Maeda K, Cao H, Kono K, Gorgun CZ, Furuhashi M, Uysal KT, et al. Adipocyte/macrophage fatty acid binding proteins control integrated metabolic responses in obesity and diabetes. Cell Metab. 2005;1:107-19.

7. Furuhashi M, Fucho R, Gorgun CZ, Tuncman G, Cao H, Hotamisligil GS. Adipocyte/macrophage fatty acid-binding proteins contribute to metabolic deterioration through actions in both macrophages and adipocytes in mice. J Clin Invest. 2008;118:2640-50.

8. Furuhashi M, Tuncman G, Gorgun CZ, Makowski L, Atsumi G, Vaillancourt E, et al. Treatment of diabetes and atherosclerosis by inhibiting fatty-acidbinding protein aP2. Nature. 2007:447:959-65.

9. Xu A, Wang Y, Xu JY, Stejskal D, Tam S, Zhang J, et al. Adipocyte fatty acidbinding protein is a plasma biomarker closely associated with obesity and metabolic syndrome. Clin Chem. 2006:52:405-13.

10. Cao H, Sekiya M, Ertunc ME, Burak MF, Mayers JR, White A, et al. Adipocyte lipid chaperone AP2 is a secreted adipokine regulating hepatic glucose production. Cell Metab. 2013;17:768-78.

11. Mita T, Furuhashi M, Hiramitsu S, Ishii J, Hoshina K, Ishimura S, et al. FABP4 is secreted from adipocytes by adenyl cyclase-PKA- and guanylyl cyclase-PKGdependent lipolytic mechanisms. Obesity (Silver Spring). 2015;23:359-67.

12. Ertunc ME, Sikkeland J, Fenaroli F, Griffiths G, Daniels MP, Cao H, et al. Secretion of fatty acid binding protein aP2 from adipocytes through a nonclassical pathway in response to adipocyte lipase activity. J Lipid Res. 2015;56:423-34

13. Lamounier-Zepter V, Look C, Alvarez J, Christ T, Ravens U, Schunck WH, et al. Adipocyte fatty acid-binding protein suppresses cardiomyocyte contraction: a new link between obesity and heart disease. Circ Res. 2009; 105:326-34.

14. Aragones G, Saavedra P, Heras M, Cabre A, Girona J, Masana L. Fatty acidbinding protein 4 impairs the insulin-dependent nitric oxide pathway in vascular endothelial cells. Cardiovasc Diabetol. 2012;11:72

15. Girona J, Rosales R, Plana N, Saavedra P, Masana L, Vallve JC. FABP4 induces vascular smooth muscle cell proliferation and migration through a MAPKdependent pathway. PLoS ONE. 2013;8:e81914.
16. Xu A, Tso AW, Cheung BM, Wang Y, Wat NM, Fong CH, et al. Circulating adipocyte-fatty acid binding protein levels predict the development of the metabolic syndrome: a 5-year prospective study. Circulation. 2007;115:1537-43.

17. Yeung DC, Xu A, Cheung CW, Wat NM, Yau MH, Fong CH, et al. Serum adipocyte fatty acid-binding protein levels were independently associated with carotid atherosclerosis. Arterioscler Thromb Vasc Biol. 2007;27:1796-802

18. Ishimura S, Furuhashi M, Watanabe Y, Hoshina K, Fuseya T, Mita T, et al. Circulating levels of fatty acid-binding protein family and metabolic phenotype in the general population. PLoS ONE. 2013;8:e81318.

19. Ota H, Furuhashi M, Ishimura S, Koyama M, Okazaki Y, Mita T, et al. Elevation of fatty acid-binding protein 4 is predisposed by family history of hypertension and contributes to blood pressure elevation. Am J Hypertens. 2012;25:1124-30.

20. Fuseya T, Furuhashi M, Yuda S, Muranaka A, Kawamukai M, Mita T, et al Elevation of circulating fatty acid-binding protein 4 is independently associated with left ventricular diastolic dysfunction in a general population. Cardiovasc Diabetol. 2014;13:126.

21. Furuhashi M, Ishimura S, Ota H, Hayashi M, Nishitani T, Tanaka M, et al. Serum fatty acid-binding protein 4 is a predictor of cardiovascular events in end-stage renal disease. PLOS ONE. 2011;6:e27356.

22. von Eynatten M, Breitling LP, Roos M, Baumann M, Rothenbacher D, Brenner $\mathrm{H}$. Circulating adipocyte fatty acid-binding protein levels and cardiovascular morbidity and mortality in patients with coronary heart disease: a 10-year prospective study. Arterioscler Thromb Vasc Biol. 2012;32: 2327-35.

23. Chow WS, Tso AW, Xu A, Yuen MM, Fong CH, Lam TH, et al. Elevated circulating adipocyte-fatty acid binding protein levels predict incident cardiovascular events in a community-based cohort: a 12-year prospective study. J Am Heart Assoc. 2013;2:e004176.

24. Karpisek M, Stejskal D, Kotolova H, Kollar P, Janoutova G, Ochmanova R, et al. Treatment with atorvastatin reduces serum adipocyte-fatty acid binding protein value in patients with hyperlipidaemia. Eur J Clin Invest. 2007:37:637-42.

25. Manickam E, Sinclair AJ, Cameron-Smith D. Suppressive actions of eicosapentaenoic acid on lipid droplet formation in 3T3-L1 adipocytes. Lipids Health Dis. 2010:9:57.

26. Warnke I, Goralczyk R, Fuhrer E, Schwager J. Dietary constituents reduce lipid accumulation in murine $\mathrm{C} 3 \mathrm{H} 10 \mathrm{~T} 1 / 2$ adipocytes: A novel fluorescent method to quantify fat droplets. Nutr Metab. 2011;8:30.

27. Prostek A, Gajewska M, Kamola D, Balasinska B. The influence of EPA and DHA on markers of inflammation in 3T3-L1 cells at different stages of cellular maturation. Lipids Health Dis. 2014;13:3.

28. Matsuo S, Imai E, Horio M, Yasuda Y, Tomita K, Nitta K, et al. Revised equations for estimated GFR from serum creatinine in Japan. Am J Kidney Dis. 2009:53:982-92.

29. Furuhashi M, Mita T, Moniwa N, Hoshina K, Ishimura S, Fuseya T, et al. Angiotensin II receptor blockers decrease serum concentration of fatty acidbinding protein 4 in patients with hypertension. Hypertens Res. 2015;38: 252-9.

30. Kletzien RF, Foellmi LA, Harris PK, Wyse BM, Clarke SD. Adipocyte fatty acidbinding protein: regulation of gene expression in vivo and in vitro by an insulin-sensitizing agent. Mol Pharmacol. 1992;42:558-62.

31. Amri EZ, Bertrand B, Ailhaud G, Grimaldi P. Regulation of adipose cell differentiation. I. Fatty acids are inducers of the aP2 gene expression. J Lipid Res. 1991;32:1449-56.

32. Distel RJ, Robinson GS, Spiegelman BM. Fatty acid regulation of gene expression. Transcriptional and post-transcriptional mechanisms. J Bio Chem. 1992:267:5937-41.

33. Coleman SL, Park YK, Lee JY. Unsaturated fatty acids repress the expression of adipocyte fatty acid binding protein via the modulation of histone deacetylation in RAW 264.7 macrophages. Eur J Nutr. 2011;50:323-30.

34. Rosen ED, MacDougald OA. Adipocyte differentiation from the inside out Nat Rev Mol Cell Biol. 2006;7:885-96.

35. Miyoshi T, Doi M, Hirohata S, Kamikawa S, Usui S, Ogawa H, et al. Olmesartan reduces arterial stiffness and serum adipocyte fatty acid-binding protein in hypertensive patients. Heart Vessels. 2011:26:408-13.

36. Mozaffarian D, Geelen A, Brouwer IA, Geleijnse JM, Zock PL, Katan MB. Effect of fish oil on heart rate in humans: a meta-analysis of randomized controlled trials. Circulation. 2005;112:1945-52. 
37. Mozaffarian D, Stein PK, Prineas RJ, Siscovick DS. Dietary fish and omega-3 fatty acid consumption and heart rate variability in US adults. Circulation. 2008;117:1130-7.

38. de Oliveira Otto MC, Wu JH, Baylin A, Vaidya D, Rich SS, Tsai MY, et al. Circulating and dietary omega- 3 and omega- 6 polyunsaturated fatty acids and incidence of CVD in the Multi-Ethnic Study of Atherosclerosis. J Am Heart Assoc. 2013;2:e000506.

39. Ninomiya T, Nagata M, Hata J, Hirakawa Y, Ozawa M, Yoshida D, et al. Association between ratio of serum eicosapentaenoic acid to arachidonic acid and risk of cardiovascular disease: the Hisayama Study. Atherosclerosis. 2013:231:261-7.

40. Yokoyama M, Origasa H, Matsuzaki M, Matsuzawa Y, Saito Y, Ishikawa Y, et al. Effects of eicosapentaenoic acid on major coronary events in hypercholesterolaemic patients (JELIS): a randomised open-label, blinded endpoint analysis. Lancet. 2007:369:1090-8.

41. Burr ML, Fehily AM, Gilbert JF, Rogers S, Holliday RM, Sweetnam PM, et al. Effects of changes in fat, fish, and fibre intakes on death and myocardial reinfarction: diet and reinfarction trial (DART). Lancet. 1989;2:757-61.

42. Dietary supplementation with $n-3$ polyunsaturated fatty acids and vitamin $\mathrm{E}$ after myocardial infarction: results of the GISSI-Prevenzione trial. Gruppo Italiano per lo Studio della Sopravvivenza nell'; Infarto miocardico. Lancet. 1999, 354:447-455

43. Gissi HFI, Tavazzi L, Maggioni AP, Marchioli R, Barlera S, Franzosi MG, et al. Effect of $n-3$ polyunsaturated fatty acids in patients with chronic heart failure (the GISSI-HF trial): a randomised, double-blind, placebo-controlled trial. Lancet. 2008:372:1223-30.

44. Lee MY, Tse HF, Siu CW, Zhu SG, Man RY, Vanhoutte PM. Genomic changes in regenerated porcine coronary arterial endothelial cells. Arterioscler Thromb Vasc Biol. 2007;27:2443-9.

45. Elmasri H, Karaaslan C, Teper Y, Ghelfi E, Weng M, Ince TA, et al. Fatty acid binding protein 4 is a target of VEGF and a regulator of cell proliferation in endothelial cells. FASEB J. 2009;23:3865-73.

46. Iso T, Maeda K, Hanaoka H, Suga T, Goto K, Syamsunarno MR, et al. Capillary endothelial fatty acid binding proteins 4 and 5 play a critical role in fatty acid uptake in heart and skeletal muscle. Arterioscler Thromb Vasc Biol. 2013;33:2549-57.

47. Tanaka M, Furuhashi M, Okazaki Y, Mita T, Fuseya T, Ohno K, et al. Ectopic expression of Fatty Acid-binding protein 4 in the glomerulus is associated with proteinuria and renal dysfunction. Nephron Clin Pract. 2014;128:345-51.

48. Okazaki Y, Furuhashi M, Tanaka M, Mita T, Fuseya T, Ishimura S, et al. Urinary Excretion of Fatty Acid-Binding Protein 4 is Associated with Albuminuria and Renal Dysfunction. PLoS ONE. 2014;9:e115429.

\section{Submit your next manuscript to BioMed Central and we will help you at every step:}

- We accept pre-submission inquiries

- Our selector tool helps you to find the most relevant journal

- We provide round the clock customer support

- Convenient online submission

- Thorough peer review

- Inclusion in PubMed and all major indexing services

- Maximum visibility for your research

Submit your manuscript at www.biomedcentral.com/submit

C Biomed Central 